\title{
The Synthesis and X-ray Studies of 6-pyrrolidinyl-2-triazolyl Purine Arabinonucleoside
}

\author{
Irina Novosjolova ${ }^{1}$, Ėrika Bizdēna ${ }^{2}$, Sergey Belyakov ${ }^{3}$, Māris Turks ${ }^{4}$, \\ ${ }^{1,2,4}$ Riga Technical University, ${ }^{3}$ Latvian Institute of Organic Synthesis
}

\begin{abstract}
C(6)-Pyrrolidinyl derivative with triazolyl moiety at C(2)-position was obtained from 2,6-bis-triazolylpurine arabinonucleoside via $\mathbf{C}(6)$-regioselective nucleophilic substituon of 1,2,3-triazolyl moiety with pyrrolidine. The obtained compound was studied by NMR, X-ray, UV/VIS and emission spectra. Pyranose form of arabinose residue and $\alpha$-configuration of the obtained compound were unambiguously proven by NMR and X-ray studies.
\end{abstract}

Keywords: purine arabinonucleosides, 2,6-bis-triazolyl purines, 1,3-dipolar cycloaddition, heteroaromatic nucleophilic substitution, X-ray

\section{INTRODUCTION}

New methods for the synthesis of $\mathrm{C}(6)$ purine derivatives have been intensively developed for decades. Search for new anticancer and antiviral agents, adenosine receptor agonists and antagonists prompted a renewed interest in purine chemistry, resulting in numerous synthetic methodologies. To the best of our knowledge, 2,6-bis-(1,2,3-triazol-1-yl)purines have been synthesized for the first time by us [1], and only their chemical reactivity remains to be determined.

Only a few scientific groups work with either 2- or 6-(1,2,3triazol-1-yl) purine nucleosides. For example, the groups of Van Calenbergh [2], Aldrich [3] and Lakshman [4] develop approaches to the synthesis of 2-triazolyl derivatives. On the other hand, 6-triazolyl derivatives have been studied by Lakshman and co-workers [5] and by the groups of Guieu and Parrain [6]. Moreover, fluorescent 8-triazolyl adenosine has been developed by the group of Grøtli. The photophysical and base-mimicking properties of the latter nucleoside have been demonstrated in DNA [7].

\section{RESULTS AND DISCUSSION}

Recently, we have reported a novel approach to the synthesis of $N^{6}$-substituted-2-(1,2,3-triazol-1-yl)adenine nucleosides [1]. Here we report a full account on the synthesis and X-ray analysis of one distinct member from this class of compounds: 9-( $\alpha$-D-arabinopyranosyl)-2-(4-(2-hydroxypropan-2-yl)-1H-1,2,3-triazol-1-yl)-6-(pyrrolidin-1-yl)-9H-purine (10).

In the beginning, a straightforward way for the synthesis of 2,6-bis-(1,2,3-triazol-1-yl)-purine nucleosides with general structure 2 was developed (Scheme 1). These compounds represent a novel structural entity in nucleoside chemistry. Their synthesis from the corresponding 2,6-diazidopurine nucleoside 1 was performed via copper (I) catalyzed azidealkyne 1,3-dipolar cycloaddition (CuAAC) reaction. It has been found that 2,6-bis-triazolyl systems 2 undergo $\mathrm{C}(6)$ regioselective nucleophilic substitution with amines. This transformation provides target compounds with general structure 3 .

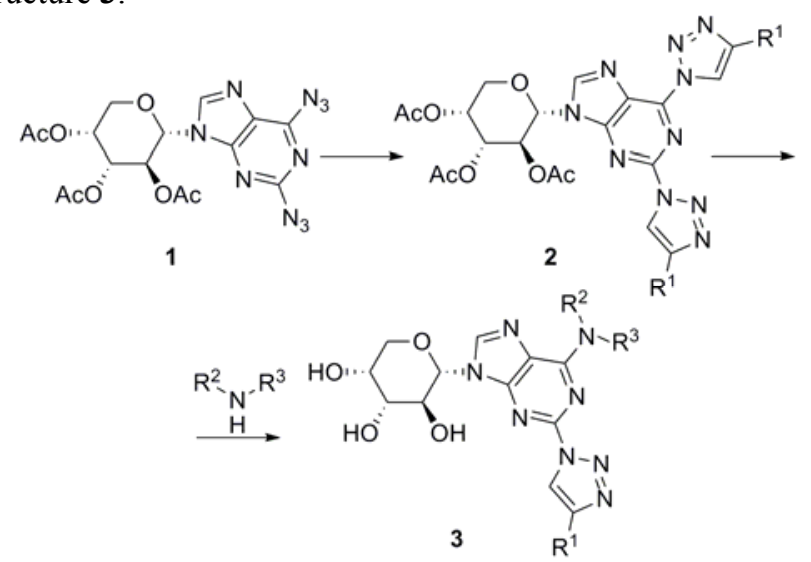

Scheme 1. A general scheme for the synthesis of 2,6-bis-triazolylpurine nucleosides and their substitution with amines at $\mathrm{C}(6)$

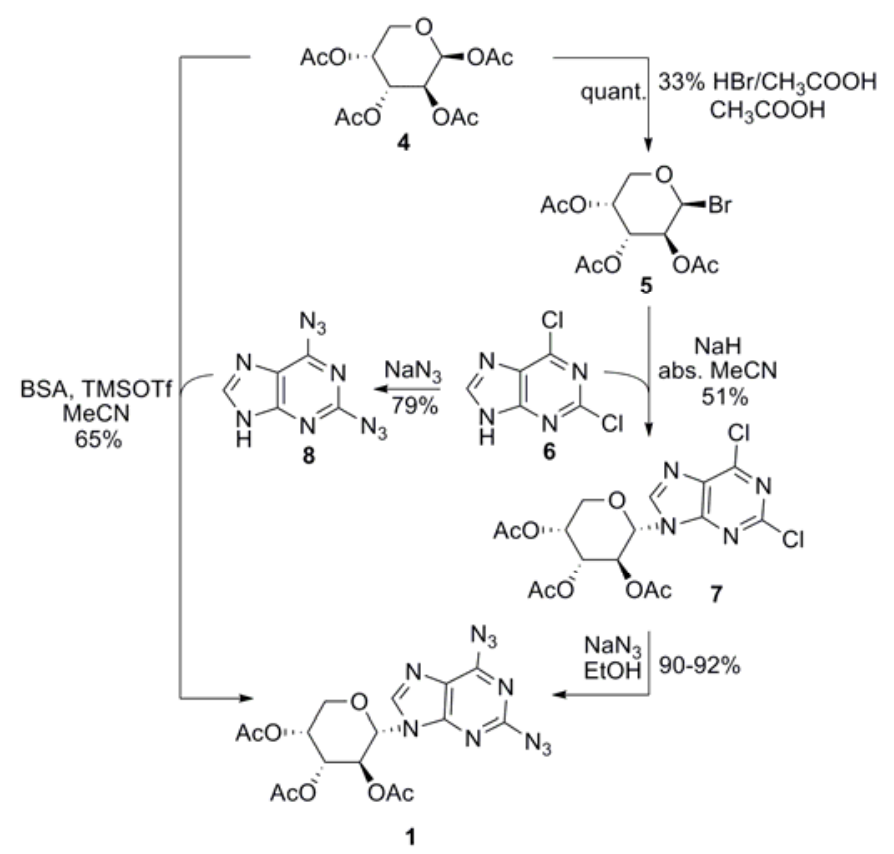

Scheme 2. Synthesis of 2,6-diazidopurine nucleoside 1

The key starting material, diazido derivative 1, was obtained by two distinct synthesis methods (Scheme 2). The first method towards $1(\mathbf{4} \rightarrow \mathbf{5} \rightarrow \mathbf{7} \rightarrow \mathbf{1}$, Scheme 2$)$ consists of the diastereoselective synthesis of glycosidic bromide $\mathbf{5}$ that undergoes stereospecific nucleophilic substitution with 
deprotonated form of 2,6-dichloropurine. The latter reaction proceeds in dry acetonitrile and provides $\alpha$-Darabinonucleoside 7 in $51 \%$ isolated yield. Aromatic nucleophilic substitution of 7 with $\mathrm{NaN}_{3}$ yielded 2,6diazidopurine nucleoside 1 in $\sim 90 \%$ yield.

Product 1 can also be synthesized by a more convergent way $(\mathbf{4} \rightarrow \mathbf{1}$, Scheme $\mathbf{2})$, where 2,6-diazidopurine $(\mathbf{8})$ is synthesized separately from $\mathbf{6}$ and $\mathrm{NaN}_{3}$. Then Vorbrüggen glycosylation of $\mathbf{8}$ with carbohydrate $\mathbf{4}$ in the presence of BSA/TMSOTf gave the desired key product 1 in $65 \%$ yield.

With diazide derivative $\mathbf{1}$ in hand, we proceeded to the $\mathrm{CuAAC}$ reaction in the presence of $\mathrm{CuSO}_{4} \cdot 5 \mathrm{H}_{2} \mathrm{O} /$ sodium ascorbate system with 2-methyl-3-butyn-2-ol in $t$ $\mathrm{BuOH} /$ acetone $/ \mathrm{H}_{2} \mathrm{O}$. Aqueous solution of acetic acid was added to the reaction mixture to speed up the process, and the mixture was stirred for 4 hours at room temperature. As a result, we obtained 2,6-bis-triazolyl derivative 9 in 75\% yield (Scheme 3).

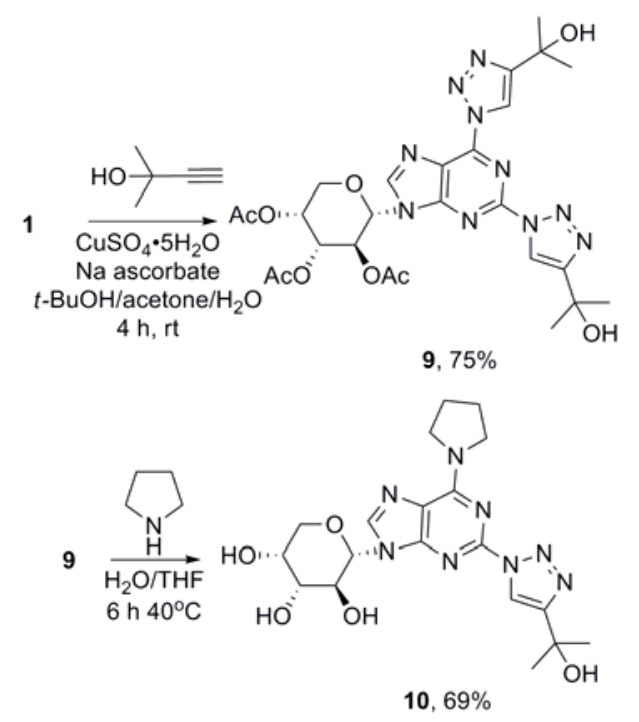

Scheme 3. Synthesis of triazolylpurine nucleoside $\mathbf{1 0}$

There are not many described applications of 1,2,3-triazolyl moieties as leaving groups till now [8]. Only the use of 6(1,2,4-triazol-4-yl)purines for their nucleophilic substitution was studied so far by the group of Robins [9]. The $\mathrm{pK}_{\mathrm{a}}$ values for 1,2,3- and 1,2,4-triazoles are very similar, 9.3 and 10.3, respectively [10]. This means that 1,2,3-triazoles might also be good leaving groups.

We have discovered that triazolyl moiety at $\mathrm{C}(6)$ of the purine base undergoes facile heteroaromatic nucleophilic substitution with pyrrolidine. Bis-triazole intermediate 9 was simply dissolved in a water/THF solution of pyrrolidine and stirred at $40{ }^{\circ} \mathrm{C}$ for $6 \mathrm{~h}$. In this way, 6-pyrrolidinyl-2-triazolyl purine arabinonucleoside $\mathbf{1 0}$ (Scheme 3) was obtained in 69\% isolated yield. The nucleophilic substitution reaction proceeds simultaneously with the cleavage of acetyl groups in the arabinose moiety.
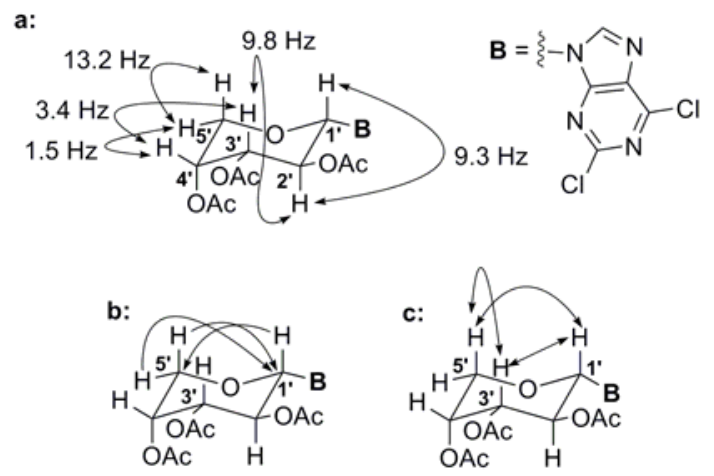

Fig. 1. Interpretation of coupling constants (a), HMBC (b) and NOESY (c) spectrum of 9-(2',3',4'-tri-O-acetyl- $\alpha$-D-arabinopyranosyl)-2,6dichloropurine 7

The relative configuration of purine nucleoside has been studied using 9-(2',3',4'-tri-O-acetyl- $\alpha$-D-arabinopyranosyl)2,6-dichloropurine 7. Heteronuclear multiple-bond correlation spectrum (HMBC) (Fig. 1: b) has proven that arabinose moiety of nucleoside exists in a pyranose form rather than in a furanose form. In turn, the NOESY spectrum (Fig. 1: c) in combination with the coupling constant analysis (Fig. 1: a) has shown that the nucleoside has the $\alpha$-configuration.

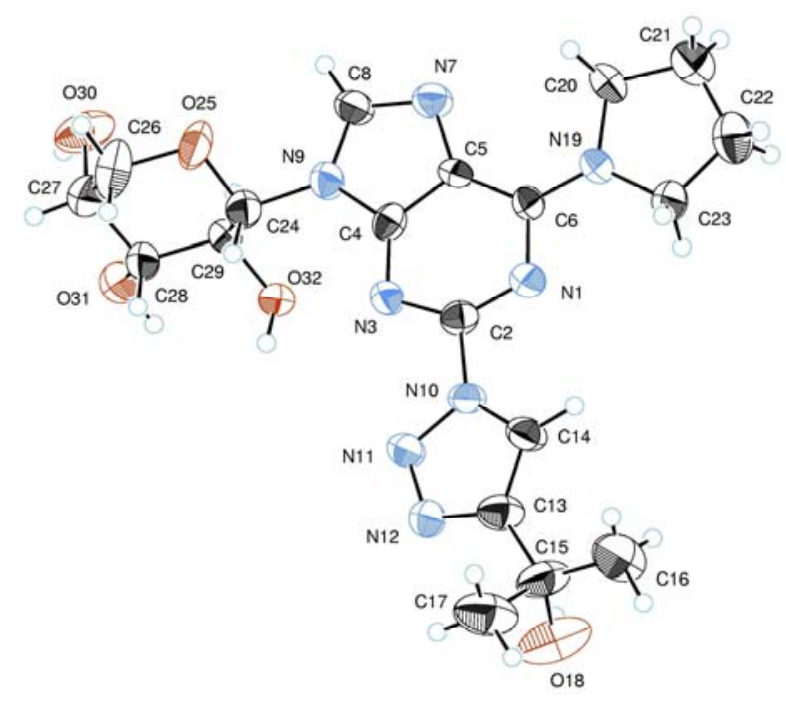

Fig. 2. ORTEP diagram of molecule $\mathbf{1 0}$

Finally, the relative configuration of $\mathbf{1 0}$ was unambiguously proven by its X-ray diffraction analysis. Monocrystals suitable for X-ray studies were obtained from acetonitrile. Crystallographic data for this compound is deposited with the Cambridge Crystallographic Data Centre as supplementary publication No. CCDC-907698. Diffraction data was collected at $-90{ }^{\circ} \mathrm{C}$ on a Bruker-Nonius KappaCCD diffractometer using graphite monochromated Mo-K $\alpha$ radiation $(\lambda=0.71073$ $\AA$ ). The crystal structure was solved by direct methods [11] and refined by full-matrix least squares [12]. All nonhydrogen atoms were refined in anisotropical approximation. Crystal data: orthorhombic; $a=7.1817(1), b=13.4005(1), c=$ 47.7523(5) $\AA ; V=4595.6(1) \AA^{3}, Z=8, \mu=0.10 \mathrm{~mm}^{-1}$; space 
group was $P 22_{1} 2$. A total of 10091 reflection intensities were collected up to $2 \theta_{\max }=56^{\circ}$; for structure refinement 3461 independent reflections with $I>3 \sigma(I)$ were used. The final $R$ factor was 0.101 .

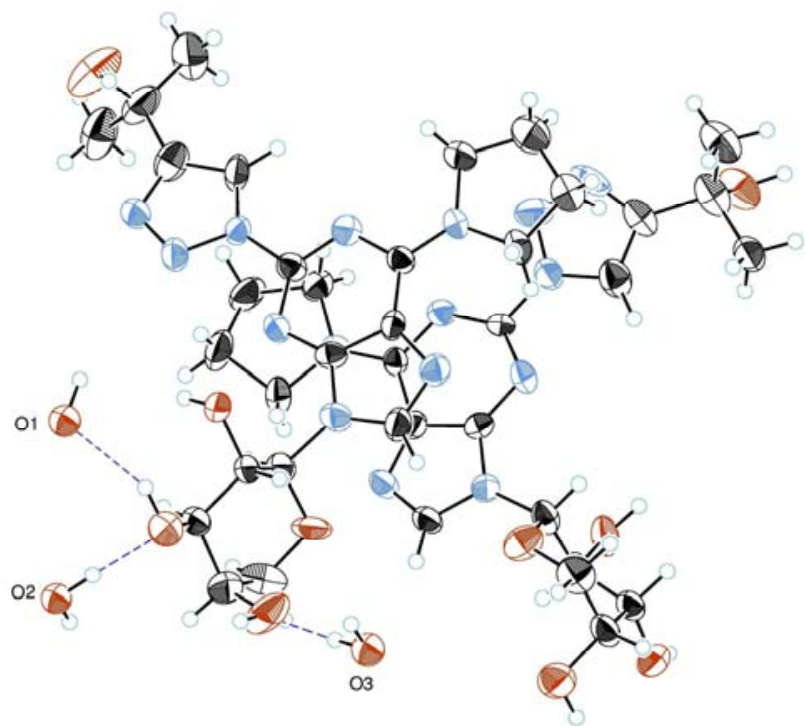

Fig. 3. A view of asymmetric unit of the compound $\mathbf{1 0} \cdot \mathrm{H}_{2} \mathrm{O}$

Fig. 2 illustrates a perspective view of molecule $\mathbf{1 0}$ with atom labels. The compound represents monohydrate of 10; in the asymmetric unit there are two independent molecules $\mathbf{1 0}$ and two water molecules, which lie in three crystallographic positions. One of these molecules lies in the special position (rotation axis 2) with $g=0.5$ (usual value of an occupation factor for this symmetry element). The second water molecule is in the general position with normal $g$-factor of 1 . The third water molecule also lies in the general position with $g=0.5$. In the crystal structure, the water molecules are held by means of $\mathrm{OH} \cdots \mathrm{O}$ type hydrogen bonds. Fig. 3 shows the content of asymmetric unit of the crystal structure.

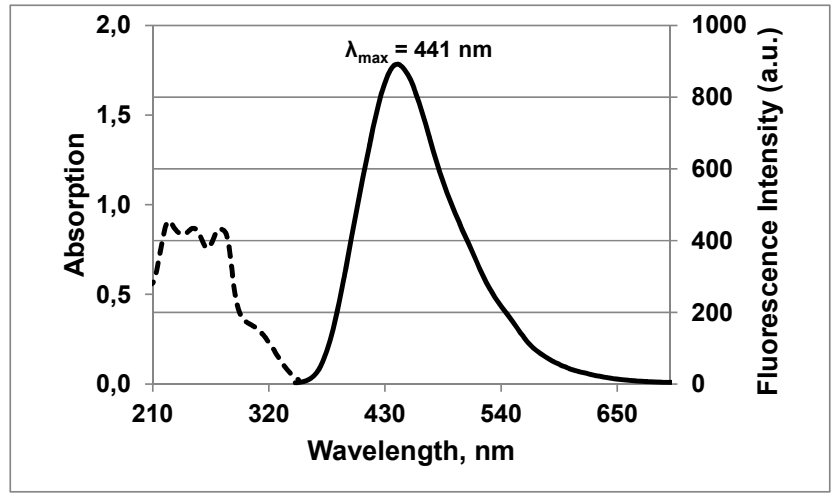

Fig. 4. Absorption (dashed line) and emission (solid line) spectra of 9- $\alpha$-Darabinopyranosyl-2-(4-(2-hydroxypropan-2-yl)-1H-1,2,3-trizol-1-yl)-6pyrrolidin-1-yl- $9 H$-purine $\mathbf{1 0}\left(7.4 \cdot 10^{-7} \mathrm{M}\right)$ in water

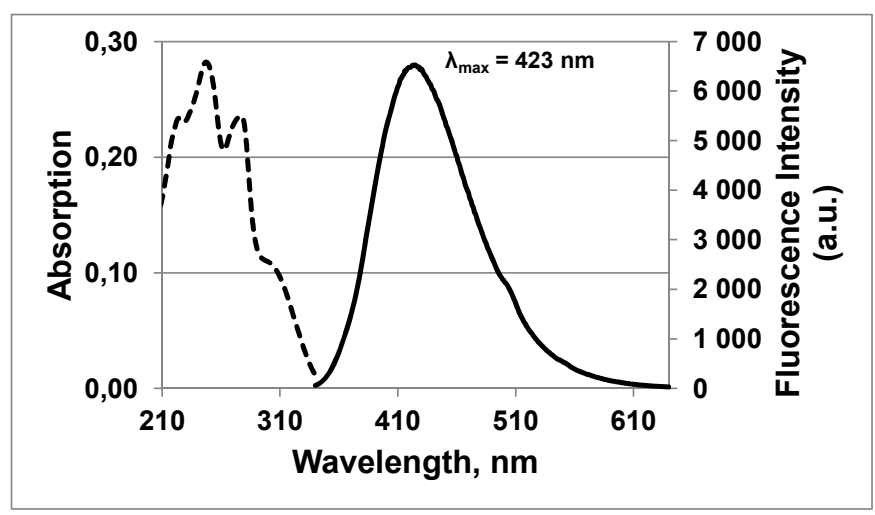

Fig. 5. Absorption (dashed line) and emission (solid line) spectra of 9- $\alpha$-Darabinopyranosyl-2-(4-(2-hydroxypropan-2-yl)-1H-1,2,3-trizol-1-yl)-6pyrrolidin-1-yl-9H-purine $\mathbf{1 0}\left(1.59 \cdot 10^{-5} \mathrm{M}\right)$ in $\mathrm{MeOH}$

We have found that product $\mathbf{1 0}$ has fluorescent properties. Initially its absorption and emission spectra were measured in DMSO [1]. However, it is more interesting to obtain the photophysical characteristics of this substance in water, which is the most common solvent for biological studies.

Interestingly, the hypsochromic shift of $18 \mathrm{~nm}$ was observed for emission spectrum, when the solvent was changed from water to methanol. Absorption and emission spectra of compound $\mathbf{1 0}$ in water are depicted in Fig. 4 and spectra in $\mathrm{MeOH}$ are depicted in Fig. 5.

\section{CONCLUSIONS}

A straightforward synthesis of 2,6-bis-(4-(2hydroxypropan-2-yl)-1H-1,2,3-triazol-1-yl)-9H-purine nucleoside has been developed. We have demonstrated that the latter compound smoothly undergoes heteroaromatic nucleophilic substitution with pyrrolidine. The obtained 6-pyrrolidinyl-2triazolyl purine arabinonucleoside has been studied by NMR, $\mathrm{X}$-ray, UV/VIS and emission spectra. The spectral analysis has revealed that the title product exists in its $\alpha$-Darabinopyranoside form. We have shown that this class of compounds possesses useful levels of fluorescence and, therefore, they are interesting structural entities for further studies.

\section{EXPERIMENTAL SECTION}

${ }^{1} \mathrm{H}-\mathrm{NMR}$ and ${ }^{13} \mathrm{C}-\mathrm{NMR}$ spectra were recorded at $300 \mathrm{MHz}$ and $600 \mathrm{MHz}$ and at $75.5 \mathrm{MHz}$ and $100 \mathrm{MHz}$, respectively. The proton signals for residual non-deuterated solvents $(\delta 7.26$ for $\mathrm{CDCl}_{3}$ and $\delta 2.50$ for DMSO-d $\mathrm{d}_{6}$ ) and carbon signals $(\delta$ 77.1 for $\mathrm{CDCl}_{3}$ and $\delta 39.5$ for DMSO- $\mathrm{d}_{6}$ ) were used as internal references for ${ }^{1} \mathrm{H}-\mathrm{NMR}$ and ${ }^{13} \mathrm{C}-\mathrm{NMR}$ spectra, respectively. Coupling constants are reported in Hz. Analytical thin layer chromatography (TLC) was performed on Kieselgel $60 \mathrm{~F}_{254}$ glass plates precoated with a $0.25 \mathrm{~mm}$ thickness of silica gel. Yields refer to chromatographically and spectroscopically homogeneous materials. Dry $\mathrm{MeCN}$ was obtained by distillation over $\mathrm{CaH}_{2}$. Commercial reagents were used as received. 
Synthesis of 9-(2',3',4'-tri-O-acetyl- $\alpha$-D-arabinopyranosyl)-2,6-diazidopurine (1) from 4 and 8

BSA $(2.70 \mathrm{~mL}, 11.0 \mathrm{~mol})$ was added to a stirred suspension of 2,6-diazidopurine (8) (2.03 g, $10.0 \mathrm{~mol})$ in dry acetonitrile $(25 \mathrm{~mL})$. The resulting mixture was stirred at $40{ }^{\circ} \mathrm{C}$ for $30-45$ min until a clear solution was obtained. Solution of tetra-Oacetylarabinopiranose (4) $((3.20 \mathrm{~g}, 10.1 \mathrm{~mol})$ in dry acetonitrile $(25 \mathrm{~mL})$ was then added, followed by TMSOTf $(0.40 \mathrm{~mL}, 2.21 \mathrm{mmol})$. The resulting reaction mixture was stirred at $75-80{ }^{\circ} \mathrm{C}$ for $3-5 \mathrm{~h}$ (TLC control). Then it was cooled to ambient temperature and ethanol $(1 \mathrm{~mL})$ was added and the mixture was stirred for $15 \mathrm{~min}$ at the same temperature followed by evaporation under reduced pressure. The residue was dissolved in $\mathrm{CH}_{2} \mathrm{Cl}_{2}(50 \mathrm{~mL})$ washed with saturated aqueous solution of $\mathrm{NaHCO}_{3}(15 \mathrm{~mL})$ and water $(15 \mathrm{~mL})$, dried over anh. $\mathrm{Na}_{2} \mathrm{SO}_{4}$ and evaporated under reduced pressure. Silica gel column chromatography $\left(\mathrm{CH}_{2} \mathrm{Cl}_{2} / \mathrm{EtOAc}\right.$ $1: 1)$ provided product $1(3.00 \mathrm{~g}, 65 \%)$ as white foam. $R_{\mathrm{f}}=0.68$ $\left(\mathrm{CH}_{2} \mathrm{Cl}_{2} / \mathrm{EtOAc}=1: 1\right)$; IR $(\mathrm{KBr}): 2991,2941,2874,2134$, $1749,1605,1575,1402,1359,1243,1222,1061,915 ;{ }^{1} \mathrm{H}-$ NMR (300 MHz, $\left.\mathrm{CDCl}_{3}\right) \delta(\mathrm{ppm}): 8.13(\mathrm{~s}, 1 \mathrm{H}, \mathrm{H}-\mathrm{C}(8)), 5.75$ $\left(\mathrm{t}, 1 \mathrm{H},{ }^{3} J_{1^{\prime}-2^{\prime}}={ }^{3} J_{2^{\prime}-3^{\prime}}=9.2 \mathrm{~Hz}, \mathrm{H}-\mathrm{C}\left(2^{\prime}\right)\right), 5.69\left(\mathrm{~d}, 1 \mathrm{H},{ }^{3} J_{1^{\prime}-2^{\prime}}=\right.$ $\left.9.2 \mathrm{~Hz}, \mathrm{H}-\mathrm{C}\left(1^{\prime}\right)\right), 5.44\left(\mathrm{ddd}, 1 \mathrm{H},{ }^{3} J_{3^{\prime}-4},=3.4 \mathrm{~Hz},{ }^{3} J_{4}{ }^{\prime}-5 \mathrm{a},=2.1\right.$ $\left.\mathrm{Hz},{ }^{3} J_{4}{ }^{\prime}-5 \mathrm{~b}^{\prime}=1.1 \mathrm{~Hz}, \mathrm{H}-\mathrm{C}\left(4^{\prime}\right)\right), 5.26\left(\mathrm{dd}, 1 \mathrm{H},{ }^{3} J_{3^{\prime}-4},=3.4 \mathrm{~Hz}\right.$, $\left.{ }^{3} J_{2^{\prime}-3^{\prime}}=9.2 \mathrm{~Hz}, \mathrm{H}-\mathrm{C}\left(3^{\prime}\right)\right), 4.16\left(\mathrm{dd}, 1 \mathrm{H},{ }^{2} J_{5 \mathrm{a}^{\prime}-5 \mathrm{~b}^{\prime}}=13.6 \mathrm{~Hz},{ }^{3} J_{4^{\prime}}\right.$ ' $\left.{ }_{5 \mathrm{a}}{ }^{\prime}=2.1 \mathrm{~Hz}, \operatorname{Ha}-\mathrm{C}\left(5^{\prime}\right)\right), 3.95\left(\mathrm{dd}, 1 \mathrm{H},{ }^{2} J_{5 \mathrm{a}^{\prime}-5 \mathrm{~b}^{\prime}}=13.6 \mathrm{~Hz},{ }^{3} J_{4}{ }^{\prime}-5 \mathrm{~b}\right.$, $\left.=1.1 \mathrm{~Hz}, \mathrm{Hb}-\mathrm{C}\left(5^{\prime}\right)\right), 2.23,2.03,1.79\left(3 \mathrm{~s}, 9 \mathrm{H}, \mathrm{H}_{3} \mathrm{COOC}-\right.$ $\left.\mathrm{C}\left(4^{\prime}, 3^{\prime}, 2^{\prime}\right)\right)$; ${ }^{13} \mathrm{C}-\mathrm{NMR}$ (75.5 MHz, $\left.\mathrm{CDCl}_{3}\right) \delta(\mathrm{ppm}): 170.1$, $169.7,169.1,156.5,154.1,153.8,141.44,120.9,81.3,70.7$, 67.9, 67.7, 67.4, 20.9, 20.5, 20.2; HRMS (ESI) calcd for $\mathrm{C}_{16} \mathrm{H}_{17} \mathrm{~N}_{10} \mathrm{O}_{7}[\mathrm{M}+\mathrm{H}]^{+}$, 461.1282; found 461.1298.

Synthesis of 9-(2',3',4'-tri-O-acetyl- $\alpha$-D-arabinopyranosyl)-2,6-diazidopurine (1) from 7 and $\mathrm{NaN}_{3}$

A solution of $\mathrm{NaN}_{3}(5.16 \mathrm{~g} ; 0.079 \mathrm{~mol})$ in water $(60 \mathrm{~mL})$ was added to a solution of $9-\left(2^{\prime}, 3^{\prime}, 4^{\prime}\right.$ '-tri-O-acetyl- $\alpha$-Darabinopyranosyl)-2,6-di-chloropurine (7) (8.88 g; $0.020 \mathrm{~mol}$ ) in EtOH $(250 \mathrm{~mL})$. The resulting mixture was stirred at $40{ }^{\circ} \mathrm{C}$ for $1 \mathrm{~h}$ and controlled by TLC (EtOAc/DCM = $1: 1 ; R_{\mathrm{f}}=$ $0.64)$. EtOH was evaporated under reduced pressure and the residue was dissolved in $\mathrm{CH}_{2} \mathrm{Cl}_{2}$ and washed with water $(2 \times 50$ $\mathrm{mL})$, again evaporated and dried over anh. $\mathrm{Na}_{2} \mathrm{SO}_{4}$. Product 1 $(8.53 \mathrm{~g} ; 93 \%)$ was obtained as white foam.

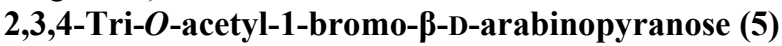

A solution of $\mathrm{HBr}$ in acetic acid $(33 \% ; 90 \mathrm{~mL})$ was added to a solution of tetra- $O$-acetyl- $\beta$-D-arabinopyranose (4) [13] $(15.02 \mathrm{~g} ; 0.047 \mathrm{~mol})$ in glacial acetic acid $(75 \mathrm{~mL})$ and stirred at room temperature for $30 \mathrm{~min}$. TLC control: Toluene/EtOAc $=2: 1\left(R_{\mathrm{f}}=0.68\right)$. The obtained mixture was diluted with cold $\mathrm{CH}_{2} \mathrm{Cl}_{2}(390 \mathrm{~mL})$ and poured into ice-water $(1 \mathrm{~L})$, then an organic layer was separated and washed with saturated aqueous solution of $\mathrm{NaHCO}_{3}$, dried over anh. $\mathrm{Na}_{2} \mathrm{SO}_{4}$ and evaporated under reduced pressure. Compound $\mathbf{5}$ is known in literature [14].

\section{9-(2',3',4'-Tri-O-acetyl- $\alpha$-D-arabinopyranosyl)-2,6-di-}

\section{chloropurine (7)}

$\mathrm{NaH}(1.27 \mathrm{~g} ; 0.053 \mathrm{~mol})$ was added to suspension of 2,6dichloropurine $(6.70 \mathrm{~g} ; 0.035 \mathrm{~mol})(6)$ in dry acetonitrile
$(200 \mathrm{~mL})$ and the resulting mixture was stirred for $1.5 \mathrm{~h}$ under argon atmosphere. Then 2,3,4-tri- $O$-acetyl-1-bromo- $\beta$-Darabinopyranose (15.52 g; $0.046 \mathrm{~mol})$ (5) was dissolved in dry acetonitrile $(170 \mathrm{~mL})$ and slowly added to the previous mixture. The obtained solution was stirred at room temperature overnight. TLC control: $\mathrm{CHCl}_{3} / \mathrm{EtOH}=9: 1$. Then EtOH $(25 \mathrm{~mL})$ was added and the mixture stirred for 15 min followed by evaporation under reduced pressure. The obtained yellow residue was dissolved in $\mathrm{CH}_{2} \mathrm{Cl}_{2}(400 \mathrm{~mL})$ and water $(100 \mathrm{~mL})$ was added, layers were separated and an organic layer was washed again with brine $(200 \mathrm{~mL})$, dried over anh. $\mathrm{Na}_{2} \mathrm{SO}_{4}$ and evaporated under reduced pressure. Silica gel column chromatography $($ Toluene/EtOAc $=2: 1)$ provided product $7(10.6 \mathrm{~g}, 51 \%)$ as yellow foam. $R_{\mathrm{f}}=0.44$ (Toluene/EtOAc = $2: 1)$; IR (KBr): 2979, 1750, 1558, 1372, 1240, 1215, 1062; ${ }^{1} \mathrm{H}-\mathrm{NMR}$ (600 MHz, DMSO-d 6 ) $\delta$ (ppm): $8.93(\mathrm{~s}, 1 \mathrm{H}, \mathrm{H}-\mathrm{C}(8)), 6.08$ (d, $\left.1 \mathrm{H},{ }^{3} J_{1^{\prime}-2},=9.3 \mathrm{~Hz}, \mathrm{H}-\mathrm{C}\left(1^{\prime}\right)\right)$, $5.68\left(\mathrm{dd}, 1 \mathrm{H},{ }^{3} J_{1^{\prime}-2},=9.3 \mathrm{~Hz},{ }^{3} J_{2^{\prime}-3^{\prime}}=9.8 \mathrm{~Hz}, \mathrm{H}-\mathrm{C}\left(2^{\prime}\right)\right), 5.47$ $\left(\mathrm{dd}, 1 \mathrm{H},{ }^{3} J_{3^{\prime}-4},=3.4 \mathrm{~Hz},{ }^{3} J_{2^{\prime}-3^{\prime}}=9.8 \mathrm{~Hz}, \mathrm{H}-\mathrm{C}\left(3^{\prime}\right)\right), 5.26$ (br.s, $\left.1 \mathrm{H}, \mathrm{H}-\mathrm{C}\left(4^{\prime}\right)\right), 4.19$ (d, 1H, ${ }^{2} J_{5 \mathrm{a}^{\prime}-5 \mathrm{~b}}$, $\left.=13.2 \mathrm{~Hz}, \mathrm{Hb}-\mathrm{C}\left(5^{\prime}\right)\right), 4.03$ $\left(\mathrm{dd}, 1 \mathrm{H},{ }^{2} J_{5 \mathrm{a}^{\prime}-5 \mathrm{~b}},=13.2 \mathrm{~Hz},{ }^{3} J_{4}{ }^{\prime}-5 \mathrm{a}^{\prime}=1.5 \mathrm{~Hz}, \mathrm{Ha}-\mathrm{C}\left(5^{\prime}\right)\right), 2.17$, 1.94, $1.72\left(3 \mathrm{~s}, 9 \mathrm{H}, \mathrm{H}_{3} \mathrm{COOC}-\mathrm{C}\left(4^{\prime}, 3^{\prime}, 2^{\prime}\right)\right)$; ${ }^{13} \mathrm{C}-\mathrm{NMR}(125$ $\left.\mathrm{MHz}, \mathrm{DMSO}-\mathrm{d}_{6}\right) \delta(\mathrm{ppm}): 170.4,170.0,169.7,153.6,152.1$, $150.7,146.9,131.0,81.4,70.6,68.5,68.3,66.8,21.2,20.9$, 20.4; HRMS (ESI) calcd for $\mathrm{C}_{16} \mathrm{H}_{17} \mathrm{Cl}_{2} \mathrm{~N}_{4} \mathrm{O}_{7} \quad[\mathrm{M}+\mathrm{H}]^{+}$, 447.0474; found 447.0470.

\section{2,6-Diazidopurine (8) [15]}

A solution of sodium azide $(8.25 \mathrm{~g}, 126.9 \mathrm{mmol})$ in water (30 $\mathrm{mL}$ ) was added to a stirred suspension of 2,6dichloropurine $(6.00 \mathrm{~g}, 31.7 \mathrm{mmol})$ in ethanol $(60 \mathrm{~mL})$. The resulting mixture was stirred and refluxed for $5 \mathrm{~min}$ and after that cooled to ambient temperature. The thick white mass was filtered, washed with cold water $(2 \times 20 \mathrm{~mL})$ and dissolved in hot $\left(60-65^{\circ} \mathrm{C}\right)$ ethanol $(200 \mathrm{~mL})$. The resulting solution was allowed to stay 3-5 hours at $0-5{ }^{\circ} \mathrm{C}$, and the formed precipitate was filtered, washed with cold ethanol $(2 \times 10 \mathrm{~mL})$ and dried under reduced pressure. Product 8 (5.00 g, 79\%) was obtained as white powder (unstable in light). $R_{\mathrm{f}}=0.65$ $\left(\mathrm{CHCl}_{3} / \mathrm{EtOH}\right.$ 9:1). M.p. $>190{ }^{\circ} \mathrm{C}$ (decomposes). IR (KBr): 2173, $2139\left(\mathrm{~N}_{3}\right) .{ }^{1} \mathrm{H}-\mathrm{NMR}\left(\mathrm{DMSO}-\mathrm{d}_{6}, 300 \mathrm{MHz}\right): 13.50(\mathrm{~s}$, $1 \mathrm{H}, \mathrm{NH}), 8.43$ (s, 1H, H-C (8)).

9-(2',3',4'-Tri-O-acetyl- $\alpha$-D-arabinopyranosyl)-2,6-bis(4-(2-hydroxypropan-2-yl)-1H-1,2,3-trizol-1-yl)-9H-purine (9)

Aqueous solution of acetic acid $(10 \mathrm{w}-\% ; 10 \mathrm{~mL})$ was added to a stirred solution of diazide $1(0.81 \mathrm{~g}, 1.76 \mathrm{mmol}, 1$ equiv.) and 2-methyl-3-butyn-2-ol $(0.86 \mathrm{~mL}, 8.80 \mathrm{mmol}, 5$ equiv.) in $t-\mathrm{BuOH}(30 \mathrm{~mL})$ and acetone $(5 \mathrm{~mL})$. A solution of sodium ascorbate (32 mg, $0.16 \mathrm{mmol}, 9.2 \mathrm{~mol}-\%$ ) in water (4 $\mathrm{mL})$ was added to a solution of $\mathrm{CuSO}_{4} \cdot 5 \mathrm{H}_{2} \mathrm{O}(24 \mathrm{mg}, 0.10$ $\mathrm{mmol}, 5.5 \mathrm{~mol}-\%)$ in water $(4 \mathrm{~mL})$, and the resulting reaction mixture was stirred at ambient temperature for 4 hours (TLC control). Then the reaction mixture was cooled in the ice bath, and dry $\mathrm{NaHCO}_{3}(2 \mathrm{~g})$ was added to neutralize acetic acid. The resulting mixture was evaporated under reduced pressure and the residue was dissolved in $\mathrm{CH}_{2} \mathrm{Cl}_{2}(80 \mathrm{~mL})$. The organic phase was washed with brine $(3 \times 80 \mathrm{~mL})$, dried over anh. 
$\mathrm{Na}_{2} \mathrm{SO}_{4}$ and evaporated under reduced pressure. Silica gel column chromatography $(\mathrm{EtOAc} / \mathrm{MeOH}=97: 3)$ provided product $9(0.83 \mathrm{~g}, 75 \%)$ as white foam. $R_{\mathrm{f}}=0.14$ (toluene EtOAc/MeOH = 97:3); IR (KBr): 3432, 2980, 2883, 1750, 1590, 1373, 1227, 1068, 1027; ${ }^{1} \mathrm{H}-\mathrm{NMR}\left(300 \mathrm{MHz}, \mathrm{CDCl}_{3}\right) \delta$ (ppm): $8.97,8.64(2 \mathrm{~s}, 2 \mathrm{H}, \mathrm{H}-\mathrm{C}($ triazole $)), 8.55$ (s, 1H, H$\mathrm{C}(8)), 6.07\left(\mathrm{~d}, 1 \mathrm{H},{ }^{3} J_{1^{\prime}-2},=9.2 \mathrm{~Hz}, \mathrm{H}-\mathrm{C}\left(1^{\prime}\right)\right), 5.83\left(\mathrm{dd}, 1 \mathrm{H},{ }^{3} J_{1}\right.$ '$\left.{ }_{2},=9.2 \mathrm{~Hz},{ }^{3} J_{2}{ }^{\prime},{ }^{\prime},=10.0 \mathrm{~Hz}, \mathrm{H}-\mathrm{C}\left(2^{\prime}\right)\right), 5.52$ (br.d, $1 \mathrm{H}^{3}{ }^{3} J_{3^{\prime}-4^{\prime}},=$ $\left.3.4 \mathrm{~Hz}, \mathrm{H}-\mathrm{C}\left(4^{\prime}\right)\right), 5.40\left(\mathrm{dd}, 1 \mathrm{H},{ }^{3} J_{3^{\prime}-4},=3.4 \mathrm{~Hz},{ }^{3} J_{2}{ }^{\prime}-3^{\prime}=10.0\right.$ $\left.\mathrm{Hz}, \mathrm{H}-\mathrm{C}\left(3^{\prime}\right)\right)$, 4.23 (dd, $1 \mathrm{H},{ }^{2} J_{5 \mathrm{a}^{\prime}-5 \mathrm{~b}},=13.2 \mathrm{~Hz},{ }^{3} J_{4^{\prime}-5 \mathrm{a}^{\prime}}=1.7 \mathrm{~Hz}$, $\left.\mathrm{Ha}-\mathrm{C}\left(5^{\prime}\right)\right), 4.12\left(\mathrm{~d}, 1 \mathrm{H},{ }^{2} J_{5 \mathrm{a}^{\prime}-5 \mathrm{~b}},=13.2 \mathrm{~Hz}, \mathrm{Hb}-\mathrm{C}\left(5^{\prime}\right)\right), 2.29$, 2.04, 1.79 (3s, 9H, H $\left.{ }_{3} \mathrm{COOC}-\mathrm{C}\left(4^{\prime}, 3^{\prime}, 2^{\prime}\right)\right), 1.74$ (s, 12H, 4($\left.\left.\mathrm{CH}_{3}\right)\right) ;{ }^{13} \mathrm{C}-\mathrm{NMR}\left(75.5 \mathrm{MHz}, \mathrm{CDCl}_{3}\right) \delta$ (ppm): 170.2, 169.7, $169.5,156.5,156.3,155.6,148.9,145.6,144.9$ (this signal was assigned from HSQC spectrum), 121.8, 119.9, 119.2, 81.6, 70.6, 68.64, 68.61, 68.2, 67.8, 67.5, 30.4, 30.3, 21.0, 20.5, 20.3; HRMS (ESI) calcd for $\mathrm{C}_{26} \mathrm{H}_{33} \mathrm{~N}_{10} \mathrm{O}_{9}[\mathrm{M}+\mathrm{H}]^{+}$, 629.2432; found 629.2453.

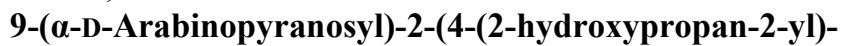
1H-1,2,3-trizol-1-yl)-6-(pyrrolidin-1-yl)-9H-purine (10)

A solution of bis-triazolyl-derivative $9(0.55 \mathrm{~g}, 0.88 \mathrm{mmol})$ and pyrrolidine $(3 \mathrm{~mL})$ in a mixture of THF $(25 \mathrm{~mL})$ and water $(1 \mathrm{~mL})$ was stirred at $40{ }^{\circ} \mathrm{C}$ for $6 \mathrm{~h}$ (TLC control). Then it was evaporated under reduced pressure, and the resulting oily residue was dissolved in a mixture of $\mathrm{MeCN}(10 \mathrm{~mL})$ and brine $(1 \mathrm{~mL})$ at $50{ }^{\circ} \mathrm{C}$ and allowed to stay at $0-5{ }^{\circ} \mathrm{C}$ for $24 \mathrm{~h}$. The resulting precipitate was filtered, washed on the filter with water $(2 \times 2 \mathrm{~mL})$ and dried under reduced pressure. Product $10(0.27 \mathrm{~g}, 69 \%)$ was obtained as white powder. $R_{\mathrm{f}}=0.29$ $\left(\mathrm{CH}_{2} \mathrm{Cl}_{2} / \mathrm{MeOH}=9: 1\right)$; IR $(\mathrm{KBr}): 3400,2974,2929,1613$, 1244, 1102, 1036; ${ }^{1} \mathrm{H}-\mathrm{NMR}$ (300 MHz, DMSO-d $\left.\mathrm{d}_{6}+\mathrm{D}_{2} \mathrm{O}\right) \delta$ (ppm): 8.49 (s, 1H, H-C(triazole)), 8.35 (s, 1H, H-C(8)), 5.40 $\left(\mathrm{d}, 1 \mathrm{H},{ }^{3} J_{1^{\prime}-2},=9.2 \mathrm{~Hz}, \mathrm{H}-\mathrm{C}\left(1^{\prime}\right)\right), 4.15\left(\mathrm{t}, 1 \mathrm{H},{ }^{3} J_{1^{\prime}-2^{\prime}}={ }^{3} J_{2^{\prime}-3^{\prime}}=\right.$ $\left.9.2 \mathrm{~Hz}, \mathrm{H}-\mathrm{C}\left(2^{\prime}\right)\right)$, 4.14-4.09 (m, 2H, $\left.\left(-\mathrm{CH}_{2}-\right)\right), 3.84$ (dd, $1 \mathrm{H}$, $\left.{ }^{2} J_{5 \mathrm{a}^{\prime}-5 \mathrm{~b}},=12.8 \mathrm{~Hz},{ }^{3} J_{4^{\prime}-5 \mathrm{a}}=1.9 \mathrm{~Hz}, \mathrm{Ha}-\mathrm{C}\left(5^{\prime}\right)\right), 3.78$ (br.d, $1 \mathrm{H}$, $\left.{ }^{3} J_{3^{\prime}-4}=3.3 \mathrm{~Hz},{ }^{3} J_{4^{\prime}-5 \mathrm{a}^{\prime}}=1.9 \mathrm{~Hz}, \mathrm{H}-\mathrm{C}\left(4^{\prime}\right)\right)$, 3.77-3.71 (m, 3H, $\left.\mathrm{Hb}-\mathrm{C}\left(5^{\prime}\right),\left(-\mathrm{CH}_{2}-\right)\right), 3.62\left(\mathrm{dd}, 1 \mathrm{H},{ }^{3} J_{3^{\prime}-4},=3.3 \mathrm{~Hz},{ }^{3} J_{2^{\prime}-3^{\prime}},=9.2\right.$ $\left.\mathrm{Hz}, \mathrm{H}-\mathrm{C}\left(3^{\prime}\right)\right)$, 2.09-1.89 (m, 4H, $\left.\left(-\mathrm{CH}_{2}-\right)\right), 1.53$ (s, 6H, 2($\left.\mathrm{CH}_{3}\right)$ ); ${ }^{13} \mathrm{C}-\mathrm{NMR}\left(75.5 \mathrm{MHz}, \mathrm{DMSO}-\mathrm{d}_{6}+\mathrm{D}_{2} \mathrm{O}\right) \delta(\mathrm{ppm})$ : $156.1,152.7,151.0,149.1,139.5$ (this signal was assigned from HSQC spectrum), 119.4, 118.5, 83.1, 73.3, 69.5, 69.1, $68.5,67.2,48.8,47.5,30.6,25.9,23.7$; HRMS (ESI) calcd for $\mathrm{C}_{19} \mathrm{H}_{27} \mathrm{~N}_{8} \mathrm{O}_{5}[\mathrm{M}+\mathrm{H}]^{+}$, 447.2104; found 447.2132.

\section{ACKNOWLEDGEMENTS}

The research has been supported by Riga Technical University grants ZP-2010/17 and FLPP-2010/12. I. Novosjolova thanks the European Social Fund for a scholarship granted within the project "Support for the Implementation of Doctoral Studies at Riga Technical University". The authors express their gratitude to Professor V.Kampars and Ms. K.Lazdoviča for UV spectra and to Professor E. Liepiņš for NMR studies of 9-(2',3',4'-tri-Oacetyl- $\alpha$-D-arabinopyranosyl)-2,6-dichloropurine (7). Grindeks JSC is acknowledged for the donation of organic solvents.

\section{REFERENCES}

1. Kovaḷovs A., Novosjolova I., Bizdēna Ē., Bižāne I., Skardziute L., Kazlauskas K. Jursenas S., Turks M. 1,2,3-Triazoles as Leaving Groups in Purine Chemistry: A Three-Step Synthesis of N6-Substituted2-Triazolyl-Adenine Nucleosides and Photophysical Properties Thereof. Tetrahedron Lett., 2012, in press.

2. Cosyn L., Palaniappan K. K., Kim S-K., Duong H.T., Gao Z-G., Jacobson K. A., Van Calenbergh S. 2-Triazole-Substituted Adenosines: A New Class of Selective $\mathrm{A}_{3}$ Adenosine Receptor Agonists, Partial Agonists, and Antagonists. J. Med. Chem., 2006, vol. 49, p. 7373-7383. http://dx.doi.org/10.1021/jm0608208

3. Gupte A., Boshoff H. I., Wilson D. J., Neres J., Labello N. P., Somu R. V., Xing C., Barry III, C. E., Aldrich, C. C. 2-Triazole Substituted Analogues of 5'-O-[ $\mathrm{N}$-(Salicyl)sulfamoyl]adenosine: Antibacterial Nucleosides Effective Against Mycobacterium tuberculosis. J. Med. Chem., 2008, vol. 51, p. 7495-7507. http://dx.doi.org/10.1021/jm8008037

4. Lakshman M. K., Kumar A., Balachandran R., Day B. W., Andrei G., Snoeck R., Balzarini J. Synthesis and Biological Properties of C-2 Triazolylinosine Derivatives. J. Org. Chem., 2012, vol. 77, N 14, p. 5870-5883. http://dx.doi.org/10.1021/jo300628y

5. Lakshman M. K., Singh M. K., Parrish D., Balachandran R., Day B. W. Azide-Tetrazole Equilibrium of C-6 Azidopurine Nucleosides and Their Ligation Reactions with Alkynes. J. Org. Chem., 2010, vol. 75, p. 2461-2473. http://dx.doi.org/10.1021/jo902342z

6. Mathew S. C., By Y., Berthault A., Virolleaud M.-A., Carrega L., Chouraqui G., Commeiras L., Condo J., Attolini M., Gaudel-Siri A., Ruf J., Rodriguez J., Parrain J.-L., Guieu R. Expeditious Synthesis and Biological Evaluation of New C-6 1,2,3-Triazole Adenosine Derivatives $\mathrm{A}_{1}$ Receptor Antagonists or Agonists. Org. Biomol. Chem., 2010, vol. 8, p. 3874-3881. http://dx.doi.org/10.1039/c0ob00017e

7. a) Dyrager C., Borjesson K., Diner P., Elf A., Albinsson B., Wilhelmsson L. M., Grotli M. Synthesis and Photophysical Characterisation of Fluorescent 8-(1H-1,2,3-Triazol-4-yl)adenosine Derivatives. Eur. J. Org. Chem. 2009, 1515-1521; http://dx.doi.org/10.1002/ejoc.200900018 b) Dierckx A., Diner P., ElSagheer A. H., Dhruval Kumar J., Brown T., Grotli M., Wilhelmsson L. M. Characterization of Photophysical and Base-Mimicking Properties of A Novel Fluorescent Adenine Analogue in DNA. Nucleic Acids Res., 2011, vol. 39, N 10, p 4513-4524. http://dx.doi.org/10.1093/nar/gkr010

8. Prashad M., Liu Y., Har D., Repič O., Blacklock T. J. 1,2,3-Triazole as a safer and practical substitute for cyanide in the Bruylants reaction for the synthesis of tertiary amines containing tertiary alkyl or aryl groups. Tetrahedron Lett., 2005, vol. 46, p 5455-5458. http://dx.doi.org/10.1016/j.tetlet.2005.06.066

9. Samano V., Miles R. W., Robins M. J. Nucleic Acid Related Compounds. 86. Nucleophilic Functionalization of Adenine, Adenosine, Tubercidin, and Formycin Derivatives via Elaboration of the Heterocyclic Amino Group into a Readily Displaced 1,2,4-Triazol-4-yl Substituent. J. Am. Chem. Soc., 1994, vol. 116, p 9331-9332. http://dx.doi.org/10.1021/ja00099a061

10. Eicher T., Hauptmann S. The Chemistry of Heterocycles, $2^{\text {nd }}$ ed.; Wiley-VCH: Weinheim, 2003, p 201 and p 209.

11. Altomare A., Burla M.C., Camalli M., Cascarano G.L., Giacovazzo G., Guagliardi A., Moliterni A.G.G., Spagna R. SIR97: A New Tool for Crystal Structure Determination and Refinement. J. Appl. $\begin{array}{llll}\text { Crystallogr.,1999, vol. } & 32, & 115-119 .\end{array}$ http://dx.doi.org/10.1107/S0021889898007717

12. Mackay S., Dong W., Edwards C., Henderson A., Gilmore C.J., Stewart N., Shankland K., Donald A. maXus, Integrated Crystallography Software, 2003, Bruker-Nonius and University of Glasgow.

13. Rusavskaya T.N., Studentsov E.P., Sokolov V.M., Zakharov V.I., Ivanov, M.A. Stereospecificity of Reactions in the Glycoside Center of Carbohydrates. III. Stereoisomeric Composition of Products of the Acetylation and Acetolysis of Methyl Arabinosides. Zh. Obshch. Khim. 1983, 53 (2), 434-42 (Russ.).

14. Garnier E. C., Liebeskind L. S. Organometallic Enantiomeric Scaffolding: General Access to 2-Substituted Oxa- and Azabicyclo[3.2.1]octenes via a Brønsted Acid Catalyzed $[5+2]$ Cycloaddition Reaction. J. Am. Chem. Soc., 2008, vol. 130, N 23, p. 7449-7458. http://dx.doi.org/10.1021/ja800664v

15. Temple C. Jr., Kussner C. L., Montgomery J. A. Studies on the Azidoazomethine - Tetrazole Equilibrium. V. 2- and 6-Azidopurines ${ }^{1}$. J. Org. Chem., 1966, vol. 31, 2210-2215. 
http://dx.doi.org/10.1021/jo01341a071

http://dx.doi.org/10.1021/jo01345a031

Irina Novosjolova obtained her B.Sc. and M.Sc. in Chemical Engineering from Riga Technical University (RTU) in 2009 and 2011, respectively. She is currently pursuing her doctoral degree under the supervision of Professor Māris Turks and Professor Ërika Bizdēna at RTU. Her research is focused on the structure and reactivity studies of bistriazolylpurine nucleosides.

I.Novosjolova has worked as a Laboratory Assistant (2006-2007), Senior Laboratory Assistant (2007-2009) and Research Assistant (2010-2012) at the Faculty of Materials Science and Applied Chemistry, Riga Technical University. Now she is a Researcher at the Institute of Technology of Organic Chemistry, RTU.

Contact data: 14/24 Azenes Str., Riga, LV-1007, Latvia

E-mail: irina.novosjolova@gmail.com

Ērika Bizdēna obtained her degree of Candidate of Chemical Sciences (equal to Dr.chem.) in 1971 with specialization in chemistry and technology of biologically active substances. Since then, Dr. Bizdēna has been working at Riga Technical University and has been promoted to the position of Full Professor in 2008. Her current research interests deal with heterocyclic and nucleoside chemistry.

Contact data: 14/24 Azenes Str., Riga, LV-1007, Latvia

E-mail: erbi@ktf.rtu.lv
Sergey Belyakov obtained his degree of Candidate of Physical and Mathematical Sciences (equal to Dr.phys.) in 1987. Until 1989 he was an Assistant at Riga Polytechnical Institute (now Riga Technical University). Since 1989, Sergey Belyakov is a Researcher at the Latvian Institute of Organic Synthesis. His research interests are mainly related to the fields of molecular structure and crystal chemistry.

Contact data: Aizkraukles Str. 21, Riga, LV-1006, Latvia

E-mail: serg@osi.lv

Māris Turks obtained his B.Sc. in Chemistry from the University of Latvia in 1998 and M.Sc. from Riga Technical University in 2000. Further, he was a doctoral student at the Swiss Federal Institute of Technology, Lausanne under the guidance of Professor Pierre Vogel, where he earned his Dr.ès.sc. degree in Synthetic Organic Chemistry in 2005.

M.Turks has worked as a Postdoctoral Associate at the Swiss Federal Institute of Technology, Lausanne in 2005 followed by appointment as SNSF Postdoctoral Fellow at Stanford University under the guidance of Professor Barry M.Trost in 2006. In 2007 he accepted an academic position at the Faculty of Materials Science and Applied Chemistry, Riga Technical University, where currently he is a Professor and the Head of the Institute of Technology of Organic Chemistry. Dr. Turks' current research interests deal with carbohydrate chemistry, functionalized heterocycles, and applications of liquid sulfur dioxide in organic synthesis.

Contact data: 14/24 Azenes Str., Riga, LV-1007, Latvia

E-mail: maris_turks@ktf.rtu.lv

Irina Novosjolova, Ērika Bizdēna, Sergejs Beḷakovs, Māris Turks. 6-Pirolidinil-2-triazolilpurīna arabinonukleozīda sintēze un rentgenstruktūranalīze

Šajā darbā sintezēts jauns 6-pirolidinil-2-triazolil-purīna nukleozīda analogs, izmantojot reǵeoselektīvu heteroaromātisko nukleofīlo aizvietošanu nukleozīda C(6) vietā. Mērķa savienojuma, 9-( $\alpha$-D-arabinopiranozil)-2-(4-(2-hidroksipropan-2-il)-1H-1,2,3-triazol-1-il)-6(pirolidin-1-il)-9H-purīna, struktūra tika pierādīta, izmantojot gan rentgenstruktūranalīzi, gan ${ }^{1} \mathrm{H}$ - un ${ }^{13} \mathrm{C}-\mathrm{KMR}$ spektrus. Pierādīts, ka molekulas ogḷhidrāta daļa pastāv $\alpha$-D-arabinopiranozes formā. Šis savienojums veido monohidrātu, ja to kristalizē no ūdens.

Ir pierādīts, ka $N^{6}$-aizvietotiem adenozīna 2-triazolilatvasinājumiem piemīt fluorescentas īpašības. Mērķa produkta emisijas spektri parāda intensīvu joslu pie $441 \mathrm{~nm}\left(\mathrm{H}_{2} \mathrm{O}\right)$ un $423 \mathrm{~nm}(\mathrm{MeOH})$.

9-( $\alpha$-D-Arabinopiranozil)-2-(4-(2-hidroksiropan-2-il)-1H-1,2,3-trizol-1-il)-6-(pirolidin-1-il)-9H-purīns ir galvenais starpsavienojums 6pirolidinil-2-triazolilpurīna arabinonukleozīda sintēzē. Mēs pirmie piedāvājam iepriekš neaprakstītu 2,6-bis-triazolilpurīna nukleozīdu sintēzes metodi. Metodes pamatā ir vara (I) katalizēta reakcija starp 2,6-diazidopurīna arabinonukleozīdu un alkīnu. Jāatzīmēe ka etiķskābes pievienošana paātrina reakciju. Stratēǵisko izejvielu, 2,6-diazidopurīna arabinonukleozīdu, var iegūt divos sintēzes ceļos: lineāri vai konverǵenti. Lineārā metode sastāv no tetraacetilarabinopiranozes bromēšanas reakcijas pirmajā solī, iegūtā atvasinājuma sekojošas reakcijas ar 2,6-dihloropurīnu otrajā un reakcijas ar nātrija azīdu trešajā solī. Savukārt konverǵentajā metodē sākumā tiek iegūts 2,6-diazidopurīns un tad tiek veikta reakcija ar tetraacetilarabinopiranozi, izmantojot Forbrugena glikolizēšanas apstākḷus, BSA/ TMSOTf klātienē.

Ирина Новосёлова, Эрика Биздена, Сергей Беляков, Марис Туркс. Синтез и рентгеноструктурный анализ 6-пирролидинил-2триазолилпуринового арабинонуклеозида.

Синтез нового аналога пуринового арабинонуклеозида, содержащего пирролидиновый заместитель в позиции С(6) и триазольный цикл в позиции С(2), был осуществлен путем региоселективного гетероароматического нуклеофильного замещения при С(6). Структура целевого продукта 9-( $\alpha$-D-арабинопиранозил)-2-(4-(2-хидроксипропан-2-ил)-1H-1,2,3-триазол-1-ил)-6-(пирролидин-1-ил)$9 H$-пурина была полностью доказена рентгеноструктурным анализом, спектрами ЯМР - ${ }^{1} \mathrm{H}$ и ${ }^{13} \mathrm{C}$. Установленно, что углеводный остаток существует в форме $\alpha$-D-арабинопиранозы. При кристализации из воды это вещество образует моногидрат.

Было доказено, что $N^{6}$ - замещеные 2-триазолилпроизводные аденозина обладают флуоресцентными свойствами. В эмиссионном спектре вышеупамянутого соединения наблюдается интенсивная полоса при 441 нм $\left(\mathrm{H}_{2} \mathrm{O}\right)$ и 423 нм $(\mathrm{MeOH})$.

Ключевым интермедиатом для получения целевого продукта является 9-(2',3',4'-три-О-ацетил- $\alpha$-D-арабинопиранозил)-2,6-бис-(4-(2хидроксипропан-2-ил)-1H-1,2,3-триазол-1-ил)-9H-пурин. Метод синтеза ранее неизвестных 2,6-бис-триазолилпуриновых нуклеозидов предложен нами впервые. Метод заключается в реакции 2,6-диазидопроизводных пурина с алкином в условиях катализа медью (I). Реакцию ускоряет добовление уксусной кислоты. Исходное вещество - 2,6-диазидопуриновый арабинонуклеозид получен двумя путями. Линеарный метод состоит из первоначальной реакции бромирования тетраацетиларабинопиранозы, реакции полученного производного и 2,6-дихлорпурина и последовательной реакцией с азидом натрия. В то время как, в конвергентном методе сперва получают 2,6-диазидопурин и потом осуществляют реакцию с тетраацетиларабинопиранозой по условиям гликозилирования по методу Форбрюггена, используя BSA/ TMSOTf. 